Chirurgia (2017) 112: 573-585

No. 5, September - October

Copyright@ Celsius

http://dx.doi.org/10.21614/chirurgia.112.5.573

\title{
The Operative Management of Flail Chest Injuries with Concomitant Sternal Fracture
}

\author{
Stefan Schulz-Drost ${ }^{1,2}$, Sebastian Krinner', Andreas Langenbach', David Merschin², Sina Grupp ${ }^{1}$, \\ Friedrich. F. Hennig ${ }^{1}$, Axel Ekkernkamp ${ }^{2}$, Andreas Mauerer ${ }^{3}$ \\ 'University Hospital Erlangen, Department of Trauma and Orthopedic Surgery, Erlangen, Germany \\ ${ }^{2}$ Department of Trauma and Orthopedic Surgery, BG Hospital Unfallkrankenhaus Berlin gGmbH, Berlin, Germany \\ ${ }^{3}$ Department of Orthopedic and Trauma Surgery, St. Theresien Krankenhaus, Nürnberg, Germany
}

Corresponding author:

Stefan Schulz-Drost, MD, PhD, FEBS EmSurg.

BG Hospital Unfallkrankenhaus Berlin gGmbH, Warener Straße 7, 12683

Berlin, Germany

E-mail: stefan.schulz-dros@gmx.de

\section{Rezumat}

Managementul operator al leziunilor de volet costal asociate cu fractură sternală concomitentă

Date generale: Leziunile de volet costal (FCI) sunt unele dintre cele mai grave leziuni toracice. Mai mult decât atât, o fractură de stern suplimentară (SF) chiar agravează rezultatele, cum ar fi durata ventilației mecanice, prin urmare o fixare chirurgicală a fracturilor poate fi luată în considerare în anumite cazuri pentru a grăbi deconectarea ventilatorului. Această lucrare urmăreşte să sublinieze managementul diferitelor tipuri de SF în FCI.

Metode: Toate cazurile tratate chirurgical (2012-2016) care au prezentat combinația FCI şi SF au fost evaluate în ceea ce priveşte detaliile clinice, morfologia fracturilor şi aspectele tehnice ale procedurii chirurgicale într-o investigație retrospectivă.

Rezultate: Toate SF $(n=15)$ au fost fixate prin osteosinteză cu plăcuță blocată printr-o abordare mediană într-o poziție în sus. Trei regiuni principale ale sternului au necesitat diferite strategii de fixare: manubriumul superior, sternul central şi inferior. Fracturile costale concomitente au fost abordate fie prin aceeaşi abordare, fie prin incizii limitate suplimentare.

Concluzii: Combinatiile dintre SF şi FCI sunt leziuni cu risc ridicat, care necesită abilități chirurgicale avansate. Ele pot fi fixate corespunzător prin osteosinteză cu placă blocată printr-o combinație de incizii limitate care utilizează diferite tipuri de plăci în funcție de tipul de SF. 
Cuvinte cheie: volet costal, fractură de stern, fractură sternală, fractură costală, osteosinteză cu placă blocată, Matrix Rib

\begin{abstract}
Background: Flail Chest Injuries (FCI) are one of the most severe thoracic injuries. Moreover, an additional sternal fracture (SF) even worsens the outcome, such as the duration of mechanical ventilation, therefore an surgical fixation of the fractures could be considered in certain cases to improve the weaning from the ventilator. This paper aims to emphasize on the management of different types of SF in FCI.

Methods: All surgically treated cases (2012-2016) that showed the combination of FCI and SF have been evaluated for their clinical details, the morphology of the fractures and the technical aspects of the surgical procedure in a retrospective investigation.

Results: All of the SF ( $\mathrm{n}=15)$ had been fixed by locked plate osteosynthesis through a median approach in a supine position. Three main regions of the sternum showed the need for different fixation strategies: the upper manubrium, central and lower corpus sterni. Concomitant rib fractures were addressed either through the same approach or through additional limited incisions. Conclusions: Combinations of SF and FCI are high risc injuries with high demand on surgical skills. They can be properly fixed with a locking plate osteosynthesis through a combination of limited incisions employing different types of plates depending on the type of SF.
\end{abstract}

Key words: Flail Chest, sternum fracture, sternal fracture, ribfracture, locking plate osteosynthesis, Matrix Rib

\section{Introduction}

Flail Chest Injuries (FCI) are one of the most severe thoracic injuries and thus associated with poor outcome. They occur in more than 16 $\%$ out of all polytrauma patients with an ISS of more than 16. Moreover an additional sternal fracture (SF) in those injuries occurs in about $10 \%$ in case out of monolateral FCI and $21 \%$ in bilateral FCI (1). As these combinations are associated with even a higher number of complications, such as the duration of mechanical ventilation, an operative fixation of the chest wall fractures could be considered in certain cases to improve the weaning from the ventilator $(2,3,4)$.

Alongside to this further complications such as prolonged instability, pain, nonunions and deformities of the ribs and the sternum could be prevented through this procedure (5).

Out of numerous historically developed methods for stabilizing the bony chest wall such as wiring, stabilization with bars and various clamp systems in the past years the osteosynthesis of ribs and sternum by means of locking plate systems became a gold standard. In the meantime, numerous methods for the surgical care of rib fractures have been described in the literature, a focus has recently been put on the efforts to establish surgical access routes as muscleconserving and limited in extent as possible to address the core regions of the unstable chest wall by means of osteosynthesis.

The challenge is to involve various thoracic regions, such as the posterior region, the axillary or lateral region and the anterior chest wall as well. In the area of the posterior and lateral thoracic wall, fractures in the positional relationship of the scapula are of particular surgical interest since they are difficult to achieve. The shoulder-bearing musculature is to be spared the best possible care, which is why muscle-conserving access routes, 
especially latissimus dorsi, are established $(6,7)$. A significant improvement in the practicability results from the minimally invasive instruments of various osteosynthesis companies available in recent years, such as trocar method and $90^{\circ}$ drills or screwdrivers (8). The supply of sternum fractures, in turn, is largely standardized with respect to the surgical approach, which can be performed easily via a median anterior approach. Here too, as a standard method, the operational stabilization by means of locking plates has established itself in various designs.

The supply of manubrium fractures is already well under investigation, as these have been observed in different morphologies. The more frequent transverse fractures nearby the angulus can be supplied very well by means of longitudinal plate osteosynthesis, while oblique manubrium fractures can be adequately stabilized by transverse plate osteosynthesis $(9,10)$. The latter occur frequently also with rib fractures, as a rule caused by a belt trauma to the car occupant.

Also, transverse fractures of the manubrium sterni or of the corpus can be caused by car accidents, for example the classic steering wheel injury, which is characterized by a mostly high transverse fracture of the sternum and bilateral rib serial fracture, leading to the unstable anterior chest wall similar to a traumatic pectus excavatum $(11,12)$. As a result of the severity of the influence on the human body, the number of ribs involved as well as the number of fractures per rib usually increase so that instability can be increased to a dramatic extent and become life-threatening. The dependence of the fracture locus of the ribs was already shown by Kilic, when he compared bilateral anteriorly with lateral fractures in the outcome (13). The position of the sternum fracture also plays a role in the risk of concomitant intrathoracic injuries as well as in the overall outcome, as Scheyerer showed (14).

In itself, the sternum is an important keystone in the stability of the thorax, since it connects the two hemithoracis with the upper seven real ribs and the adjacent ribs 8-10 and ensures stability for the thoracic organs. If the sternum ceases, painful instabilities as well as malformations with deformation of the anterior chest wall can result, which are to be treated accordingly, and with appropriate indication by surgical fixation (15-17). If, on the other hand, the sternum is accompanied by rib fractures, complex instabilities of the thoracic wall may develop, especially with ribs on both sides. In addition to the resulting clinical dangers and complications, a complex situation also arises from the surgical point of view, which must be adequately addressed. Known and established methods of rib and sternum stabilization must be combined in sensible combinations in order ultimately to stabilize the whole chest wall in a sufficient manner.

However the operative treatment of different patterns of injuries to the chest wall and a large number of rib fractures may be a challenge for the surgeon. This paper aims to emphasize on the management of different types of sternal fractures in flail chest injuries as the sternum is meant to be an important capstone for the stability of the chest wall, especially of its anterior aspect.

\section{Material and Method}

All of the operative fixations of the sternum out of the own collective (2012-2016) had been checked for concomitant fractures of the ribs in a retrospective investigation. Those cases which showed the combination of FCI and SF had been evaluated for their clinical details, such as epidemiologic aspects, concomitant injuries, clinical treatment and outcome. Moreover the morphology of the chest wall fractures as well as the technical aspects of their operative treatment had been investigated.

Particular attention was paid to the precise localization of the sternum fracture, as well as to the fracture course and the observed dislocation or instability. Taking into account the overall injury pattern and the cause of the accident, it was examined to what extent different sternum fractures can be attributed to different injuries of the ribs. 


\section{Results}

There were 15 patients included into the study. All of the SF had been fixed by locked plate osteosynthesis (MatrixRib ${ }^{\circledR}$, DePuySynthes, Oberdorf, Switzerland) through a median approach in a supine position.

Out of the patients of the collective, 4 patients had additional unilateral rib fractures with unstable fracture patterns and 11 with involvement of both hemithoracis. An operative stabilization of the rib fractures was required with unilateral participation in 5 cases and with a bilateral involvement in 4 cases. The Table 1 provides detailed information.

Three main types of sternal fractures could be found with the necessity of different fixation strategies: fractures with involvement of the upper manubrium, central SF and those at the lower aspect of the corpus sterni.

\section{Upper Manubrium fractures}

The upper manubrium includes the area from the jugulum to the lower edge of the first rib. In the group no transverse fractures of this area were observed, but 2 oblique fractures and 2 complex fractures, which had an oblique or longitudinal fracture in combination with an underlying transverse fracture. The special feature of these fractures was the rotatory instability of the shoulder girdle resulting in a fracture gap and the loss of protection of the upper mediastinum. In addition to this, rib fractures were found, which showed an oblique series course from proximal nearby the sternum to distal in a more lateral position, usually caused by a seatbelt (Fig. 1).

The surgical management had to address the rotatory instability, which after median access and treatment of the accompanying
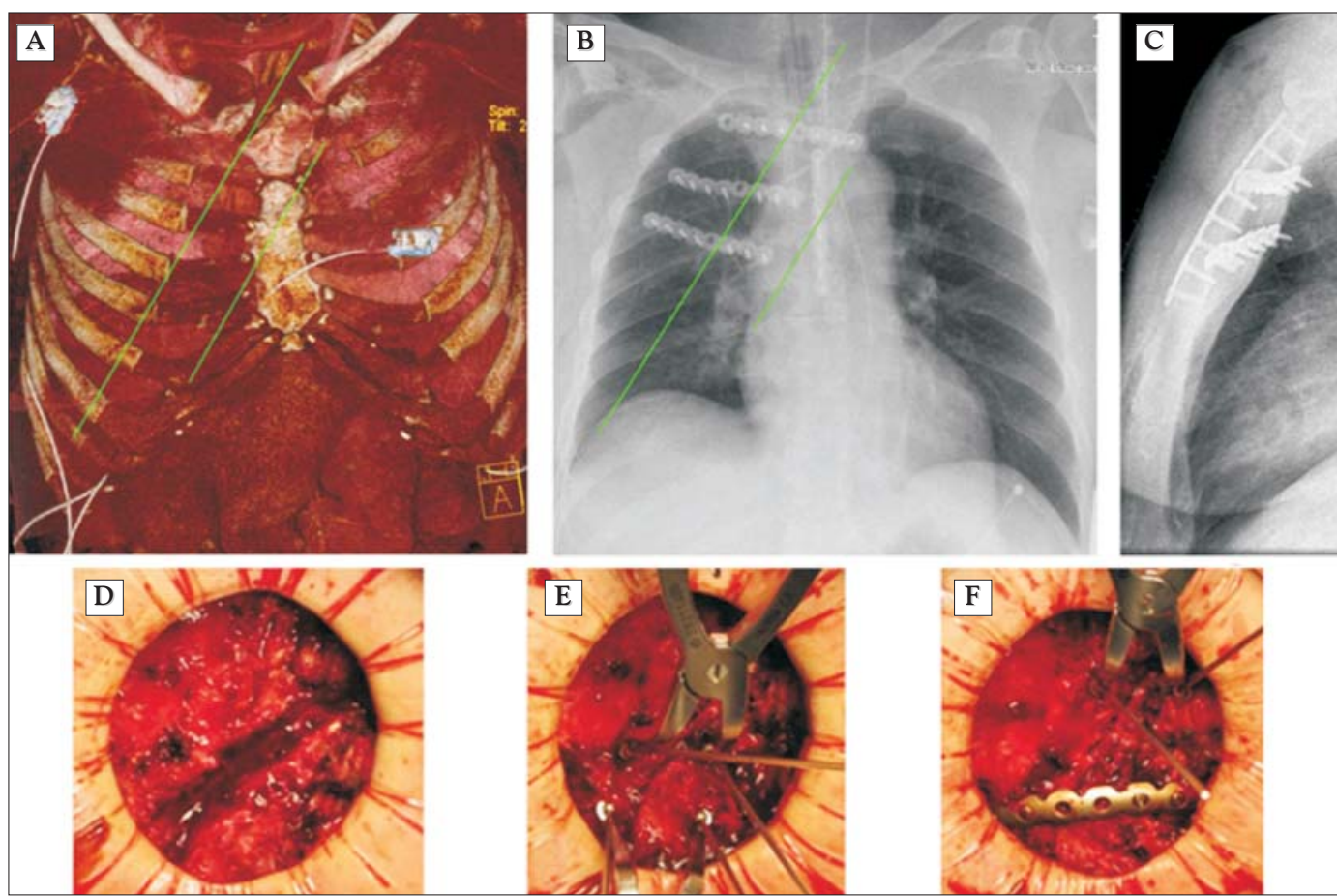

Figure 1. Sternum fracture with involvement of the upper manubrium: oblique fracture - the higher lap belt injury. (A) Often caused by a lap belt injury in smaller car occupants the unstable fractures show severe dislocation with a gap in front of the upper mediastinum and instability of the shoulder girdle (Case 3). Often series of ribs are broken following the direction of the lap belt. (B) The oblique fracture had been stabilized by a transversal plate on the 1st pair of ribs, the adjacent ribs had been treated by costosternal plate (2nd rib) and plating (3rd rib). The second sternal fracture which involved the upper corpus sterni received a longitudinal plate. (C) the sagittal profile has been restored. (D) dislocated oblique manubrium fracture (Case 2). (E) reduction using compression wires (DePuySynthes, Switzerland) (F) fixation with the first of two transverse plates. 
Table 1. Patients with fracture of the sternum and concomitant rib fractures

\begin{tabular}{|c|c|c|c|c|c|c|c|c|}
\hline & gender & $\begin{array}{l}\text { age } \\
\text { (y) }\end{array}$ & $\begin{array}{l}\text { mechanism } \\
\text { of injury }\end{array}$ & $\begin{array}{l}\text { type of sternal } \\
\text { fracture }\end{array}$ & $\begin{array}{l}\text { 3ib fractures } \\
\text { right side }\end{array}$ & $\begin{array}{l}\text { Rib fractures } \\
\text { left side }\end{array}$ & $\begin{array}{l}\text { Treatment: } \\
\text { SF } \\
\text { Ribs right } \\
\text { Ribs left }\end{array}$ & $\begin{array}{l}\text { concomitant } \\
\text { injuries }\end{array}$ \\
\hline \multicolumn{9}{|c|}{ Upper manubrium } \\
\hline 1 & Male & 53 & $\begin{array}{l}\text { mvc, restrained } \\
\text { car occupant }\end{array}$ & $\begin{array}{l}\text { Oblique } \\
\text { manubrium }\end{array}$ & --- & $\|-\mathrm{Vl}$ & $\begin{array}{l}2 \text { plates transverse } \\
\text { Rib suture }\end{array}$ & $\begin{array}{l}\text { polytrauma: severe head injury, } \\
\text { midface fractures, vertebral column } \\
\text { fractures (cervical-, thoracic- and } \\
\text { lumbar spine) }\end{array}$ \\
\hline 2 & Female & 21 & $\begin{array}{l}\text { mvc, restrained } \\
\text { car driver, trapped }\end{array}$ & $\begin{array}{l}\text { Oblique } \\
\text { manubrium }\end{array}$ & $\|-\mathrm{VIII}$ & -- & 2 plates transverse & $\begin{array}{l}\text { polytrauma: lung contusion bilateral, } \\
\text { pneumothorax bilateral, bilateral } \\
\text { carotid dissection, cerebral infarction, } \\
\text { midface fractures, rupture of liver and } \\
\text { spleen }\end{array}$ \\
\hline 3 & Female & 64 & $\begin{array}{l}\text { mvc, restrained } \\
\text { car driver, trapped }\end{array}$ & $\begin{array}{l}\text { oblique manubrium } \\
\text { and corpus }\end{array}$ & II-IX & I, II & $\begin{array}{l}3 \text { plates transverse } \\
\text { and one plate } \\
\text { longitudinal }\end{array}$ & $\begin{array}{l}\text { polytrauma: vertebral column } \\
\text { (thoracic and lumbar spine fractures), } \\
\text { proximal fracture of the tibia, complex } \\
\text { fracture of the distal tibia and talus } \\
\text { opposite site }\end{array}$ \\
\hline 4 & Female & 80 & $\begin{array}{l}\text { fall on the back, } \\
4 \mathrm{~m} \text {, impact of } \\
\text { the chin }\end{array}$ & $\begin{array}{l}\text { two level transverse } \\
\text { and midline split }\end{array}$ & II-IV & II-IV & $\begin{array}{l}\text { „H“-Plate (customized) } \\
\text { Ribs conservative }\end{array}$ & $\begin{array}{l}\text { polytrauma: traumatic brain injury; } \\
\text { vertebral column fractures }\left(5^{\text {th }} \text { thoracic }\right. \\
\text { vertebra), fracture of the mandibular, } \\
\text { bilateral fracture of the clavicle }\end{array}$ \\
\hline \multicolumn{9}{|c|}{ Central sternum } \\
\hline 5 & Male & 47 & $\begin{array}{l}\text { car driver, } \\
\text { steering wheel }\end{array}$ & Transverse manubrium & $\|-\mathrm{VII}$ & $\|-V\|$ & $\begin{array}{l}\text { two longitudinal plates } \\
\text { ESCR } 5 \text { th rib }\end{array}$ & Cardiac contusion \\
\hline 6 & Male & 49 & $\begin{array}{l}\text { truck driver, } \\
\text { steering wheel }\end{array}$ & transverse manubrium & $\|-V I I I$ & $\|-\mathrm{VIII}$ & $\begin{array}{l}\text { longitudinal plate } \\
\text { re: IV+V } \\
\text { li. III+IV }\end{array}$ & $\begin{array}{l}\text { Polytrauma, Pneumothorax bilateral, } \\
\text { femur fracture }\end{array}$ \\
\hline 7 & Female & 73 & Fall & Oblique corpus $3^{\text {rd }}$ ICS & $\|-V I I$ & $\| I-V I I I$ & $\begin{array}{l}\text { ESCR III+IV } \\
\text { Costosternal VII bilateral }\end{array}$ & Nasal bone \\
\hline 8 & Male & 27 & $\begin{array}{l}\text { motorcyclist } \\
\text { crashed against car }\end{array}$ & transverse manubrium & $|-V| \mid$ & -- & $\begin{array}{l}\text { two plates longitudinal } \\
\text { Rib suture }\end{array}$ & $\begin{array}{l}\text { clavicle fracture midshaft left } \\
\text { (ORIF plate), vertebral spine cervical } \\
6^{\text {th }}, 7^{\text {th }}, \text { thoracic } 1^{\text {st }}\end{array}$ \\
\hline 9 & Male & 64 & Car driver & Tranverse multiple & $\|-\mathrm{V}$ & $\|-\mathrm{V}$ & $\begin{array}{l}\text { Two long longitudinal } \\
\text { plates, ribs conservative }\end{array}$ & Thoracic spine Th3/4 \\
\hline 10 & Male & 54 & Car driver & Transverse $3^{\text {rd }}$ ICS & IV-VI & $\|-\mathrm{VI}$ & $\begin{array}{l}\text { Two long longitudinal } \\
\text { plates, ribs conservative }\end{array}$ & $\begin{array}{l}\text { pulmonary contusion; pleural effusion; } \\
\text { clavicle fracture; } 2^{\text {nd }} \text { lumbar vertebral } \\
\text { body }\end{array}$ \\
\hline 11 & Male & 19 & Car driver & Transverse $3^{\text {rd }}$ ICS & $\|-\| \|$ & IV-VII & $\begin{array}{l}\text { Two longitudinal plates, } \\
\text { Rib sutures }\end{array}$ & Right midshaft clavicle fracture \\
\hline 12 & Male & 57 & Car driver & Oblique $3^{\text {rd }}-4^{\text {th }}$ ICS & IV-VII & III-XI & $\begin{array}{l}\text { Two longitudinal plates, } \\
\text { rib sutures }\end{array}$ & Lung contusion, hemothorax \\
\hline 13 & Male & 81 & Sled crash & Transverse multiple & $\mathrm{IV}+\mathrm{V}$ & $\mathrm{III}+\mathrm{IV}$ & $\begin{array}{l}\text { Two long longitudinal } \\
\text { plates, ribs conservative }\end{array}$ & Lung contusion, resp. insufficience \\
\hline \multicolumn{9}{|c|}{ Lower sternum } \\
\hline 14 & Male & 51 & burying & Transverse $4^{\text {th }}$ ICS & $\begin{array}{l}\text { I-XI multiple } \\
\text { sides }\end{array}$ & $\begin{array}{l}\text { I-X multiple } \\
\text { sides }\end{array}$ & $\begin{array}{l}\text {-Bilateral costosternal } 7^{\text {th }} \text { rib. } \\
\text {-IV-VII post.-lat.-ant. } \\
\text {-III-V lat. }\end{array}$ & $\begin{array}{l}\text { spinous processes th } 6-10 \text {, } \\
\text { Dlssection Th8/9, thoracic vascular } \\
\text { injury }\end{array}$ \\
\hline 15 & male & 76 & Fall & Oblique $5^{\text {th }}$ ICS & --- & III-VII & $\begin{array}{l}\text { two longitudinal plates, } \\
\text { rib IV-VI }\end{array}$ & Lung contusion \\
\hline
\end{tabular}

All SF had been stabilized by locked plate osteosynthesis. Those patients who showed an involvement of the upper manubrium were highly associated with severe concomitant injuries. Most of the patients showed SF at its central part with a variety of different patterns of rib fractures depending on the mechanism of injury. Steering wheel injuries showed transverse SF and bilateral multiple fractures series of the ribs with respiratory insufficiency. A couple of cases were sufficiently treated by an isolated sternal plating and sutures of ribs or their conservative treatment in undisplaced fractures.

Lower SF could be stabilized by longitudinal plating as well in one case with fixation on the xiphoid process. Alternatively costo-sternal plating provides reliable stability as well as the use of special plates eg. in a "T" shape. 
injuries occurred by a reduction of the main fragments by bilateral compression. This could be obtained either by means of a pointed forceps or by means of special compression wires (DePuySynthes, Oberdorf, Switzerland) (Fig. $1 D-F)$.

The osteosynthesis is then performed to neutralize the load vector by a transverse plate osteosynthesis on the first pair of ribs, including the manubrium sterni, and in the case of an additional transverse fracture of the manubrium in 2 cases by a specially shaped plate (T or I form, Fig. 2) or with another longitudinal sternum plate (Fig. 1 B,C). Accompanying unstable rib fractures were stabilized costosternal in the sternum near area and in the sternum remote area on the rib itself by locking plate osteosynthesis (Fig. 2B) (18).

\section{Central SF}

In the case of a centrally located sternum fracture, extending from the lower manubrium to the lower corpus third, we found 5 transverse fractures, 2 oblique fractures, and 2 multiple fractures. Transverse fractures were frequently associated with bilateral rib series fractures. As a rule after steering wheel injury, these $(\mathrm{N}=2)$ affected all ribs below the plane of the sternal fracture with a symmetrical fracture pattern. In this case, anterior fractures, which extend up to the osteochondral transition of the rib and usually involves the cartilage need to be differentiated from the anterolateral fractures which led to the fracture of the rib outside the osteochondral transition (Fig. 3, 4). The anterolateral segmental fracture involving the $2^{\text {nd }}$ to $8^{\text {th }}$ rib, in combination with a transverse manubrium fracture, had the most severe courses.

The sternal transverse fracture was stabilized adequately in all cases by a (double) longitudinal plate osteosynthesis (Fig. 3 D,F). Accompanying ribs were stabilized by a crosslong plateosteosynthesis from rib to sternum to the rib, and in the case of the bi-anterolateral fracture by means of anatomical plate osteosynthesis via an additional axillary approach (Fig. 3, 4).

In the case of the oblique sternum fracture, an osteosynthesis was also carried out by means of 2 longitudinal plates in an offset configuration, so that the respective fracture line was
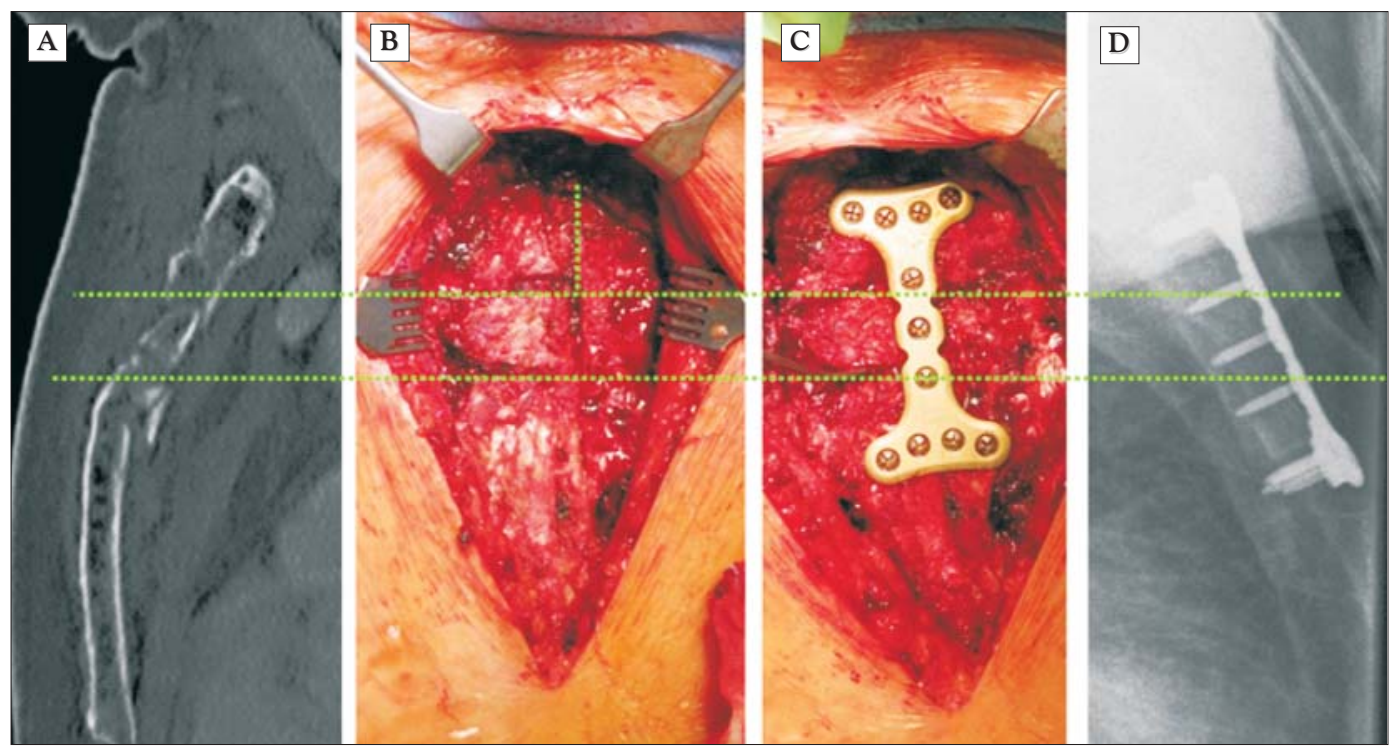

Figure 2. Complex manubrium fracture with multilevel transverse and longitudinal fractures as well as involvement of the upper corpus sterni (case 4). (A) sagittal CT Scan shows comminuted situation. (B) situs after median anterior approach. (C) stabilization with special Plate in "I" Design (Matrix Rib®, DePuySynthes, Switzerland). (D) the sagittal profile had been fully restored in this case. 

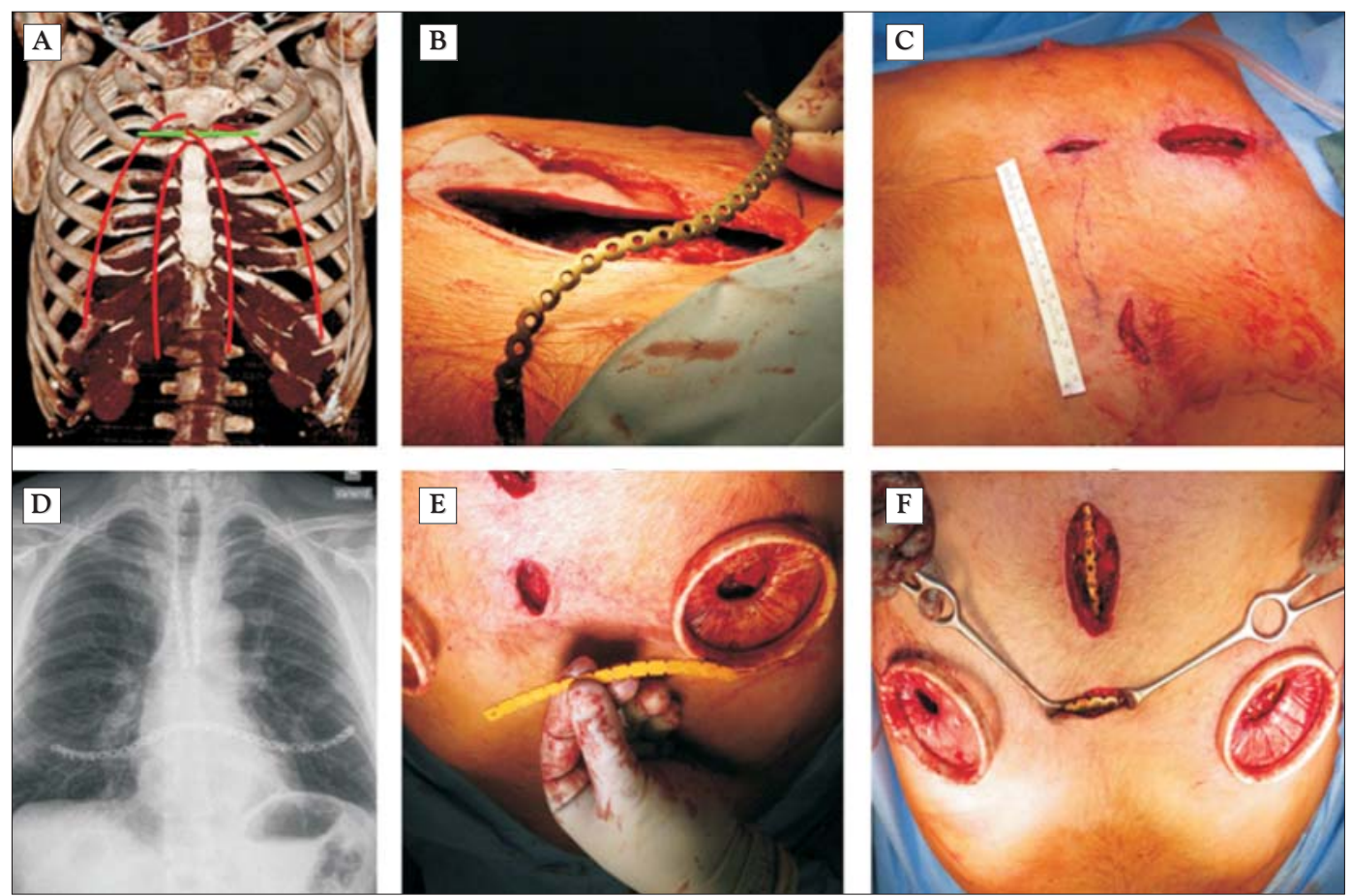

Figure 3. Steering wheel injury with anterior flail chest (case 5). (A) Bilateral fractures series of rib II-VII showing a nearly symmetric pattern of injury below the transverse fracture of the lower manubrium. (B) Elastic Stable Chest Repair (ESCR) can be carried out through a large, open approach employing a long plate which hab been bend to the shape of the ribs. (C) Alternatively MIPO procedure could be employed for ESCR. Limited incision for the management of the upper sternal fracture(right side), limited median incision in front of the lower sternum, and bilateral limited incisions at the edge of the mammilles. (D) Postoperative result: ESCR. sternal stabilization with two longitudinal plates, rib stabilization with a long costo-sterno-costal plate on the 5 th pair of ribs. $E$ the bending template is aligned to the original shape of the 5th rib. (F) All plates had been successfully fixed in situ to the sternum and the ribs through very limited incisions.

bridged in the center of the plate (Fig. 5). Accompanying rib fractures were secured to the sternum by means of sutures, and, in more distance to the sternum, by means of additional plate osteosynthesis. These fractures were managed via the anterior approach.

Multiple SF led to a complex instability of the anterior chest wall, with the sternum itself having the greatest share of instability. We saw 2 multiple transverse fractures in the sense of a segmental sternum fracture and no comminuted debris fractures. Accompanying rib fractures were limited in all cases to the cartilaginous area directly adjacent to the sternum. They were fixed costosternal by means of sutures (PDS $1 \mathrm{~mm}$, Ethicon, Summerville, NJ, USA). The sternum fractures, on the other hand, were adequately stabilized by means of a bilateral longitudinal plate osteosynthesis and thus the inclusion of the entire sternum (Fig. 6). These injuries could also be managed in isolation via the medial anterior approach.

\section{Lower SF}

A further challenge are fractures of the lower sternal area, especially from the $5^{\text {th }}$ intercostal space, corresponding to the lower third of the sternal corpus. The xiphoideus processus, which is volumetrically or slighter depending on the anatomy of the patient, as well as the ribs 5-7, which bilaterally end up in a mostly oblique angle at the sternum. Thus, a lower sternum transverse fracture leads to the avulsion of the lower ribs, including the rib arch. Frequently 

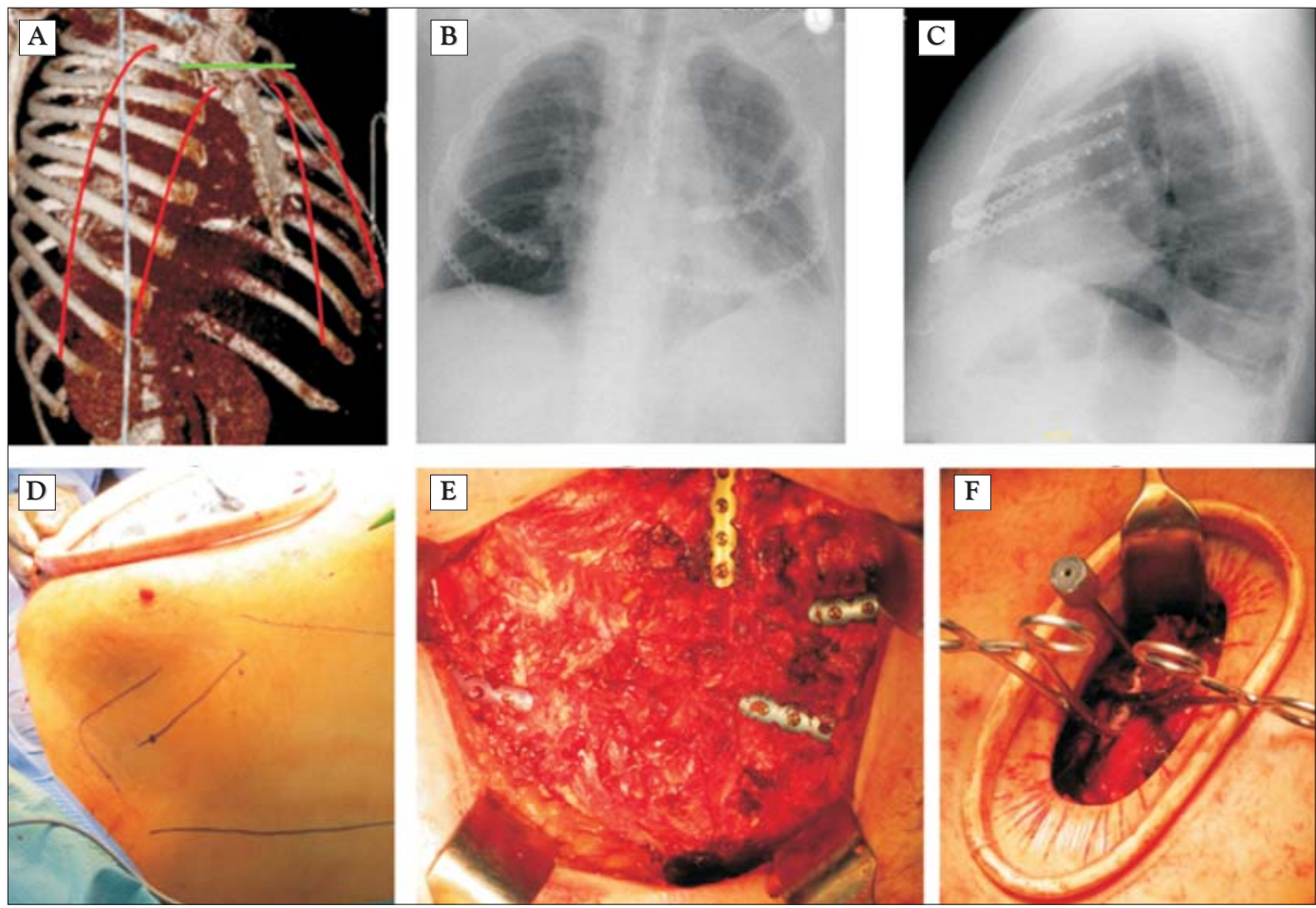

Figure 4. Steering wheel injury with bilateral anterolateral Flail Chest (case 5). (A) Bilateral multiple fractures series anterolateral involving rib II-VIII showing a nearly symmetric pattern of injury below the transverse fracture of the lower manubrium. (B) Postoperative result: the 4th and 5th rib had been stabilized on the right side, the 3rd and 4th one on the left side. (C) The sternum has been fixed with a longitudinal plate, thus the sagittal profile has been restored. (D) The patient had been treated in a supine position. The median-anterior approach had been already etablished, the drawn line indicated the axillar incicion. (E) Through the median-anterior approach the sternum could be fixed (gold plate) as well as the anterior parts of the involved ribs bilaterally. (F) The limited axillary approach allows to fix the lateral parts of the plates to the ribs which are intended for stabilization
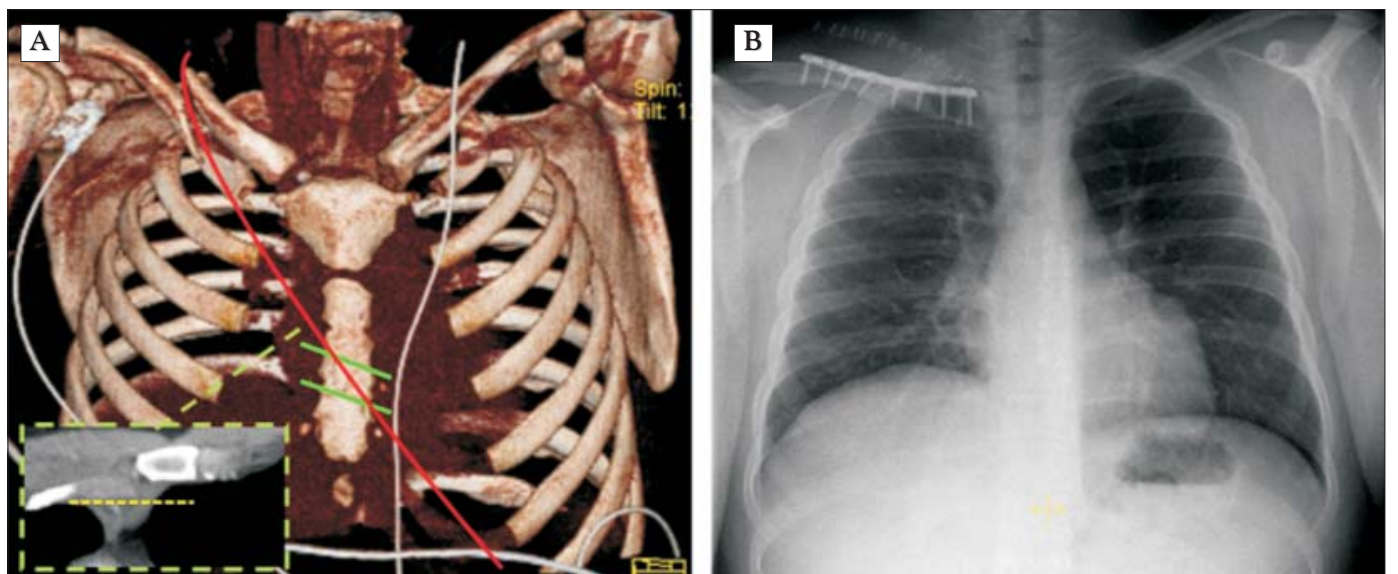

Figure 5. Oblique fracture at the corpus sterni due to seat belt injury. (A) A midshaft fracture of the clavicle and fractures of the cartilages at rib II and III present as concomitant injuries. The tip of the 3rd rib on the right side showed retrosternal dislocation and instability (CT Scan, yellow line). (B) The postoperative result shows successful plating of the clavicle and the plates on the sternum in an offset configuration. 


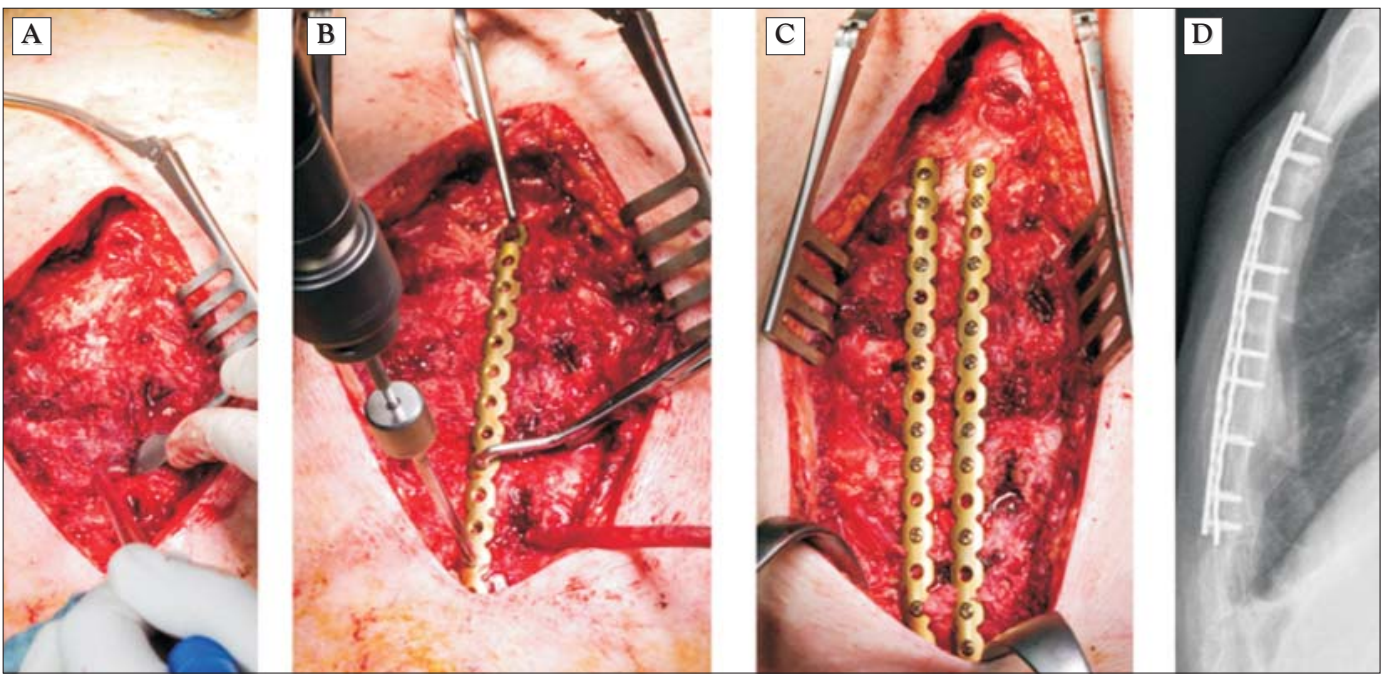

Figure 6. A multilevel transverse fracture of the corpus sterni (case 13). (A) After the median anterior approach had been done, the periosteum is dissected cautiously from the edge of the sternum in order to prevent injuries to the mammaria vessels and the mediastinal organs. Depressed fragments can be elevated through this approach and reductions clamps may be inserted through it. (B) The first plate had been aligned in parallel to the sternal edge and temporarily fixed with pointed ball forcepses through the above described approach. A $90^{\circ}$ drill guide and a depth limited drill bit of appropriate length (=sternal thickness) allow to perform the screw holes in a very safe procedure. (C) Two long plates in parallel provide anatomic reduction of the comminuted sternum and its proper stabilization. (D) Postoperative result in a lateral view of a chest X-Ray

below the fracture there is no longer the possibility to fill enough holes of the plate, which is why we stabilized one case by means of costosternal plate osteosynthesis on the $7^{\text {th }}$ rib (Fig. $7 \mathrm{~A}, B$ ). On both sides the result is a very stable construct with good elastic functionality. In the case of an obliquely extending lower sternum fracture, a dissection of the lower rib arch resulted which had been managed by a costosternal plate osteoynthesis, for example on the $7^{\text {th }}$ rib, what is sufficient, however, to be monolateral. However, such a case was not observed in the local collective. A further possibility of supplying distally located transverse fractures is provided by T-shaped or I-shaped plates, which then offers the possibility of 3 - 4 screws in the sternum corpus, in a transverse arrangement, and thus provides adequate stability.

\section{Additional Surgical Approaches}

Concomitant rib fractures were addressed either through the same approach or through additional limited incisions to the anterolateral or lateral chest wall.

Through the medial anterior approach, rib fractures could be managed in all cases up to the osteochondral junction or close to the same. For this purpose, the dissection of the major pectoral muscle is necessary, which provides a very good access to the anterior chest wall. Laterally from the osteochondral transition fractures could be addressed either by a submammary edge incision, for example, in the context of an advanced minimized costosterno-costal plate osteosynthesis in anterior flail chest (minimal invasive plate osteosynthesis, MIPO, Fig. $3 C$-F). The standard axillary approach is established for laterally located fractures or even anterolateral fractures of the ribs (Fig. $4 D, F$ ). This provides a very good accessibility of 4 - 6 ribs per side for adequate muscle-conserving soft tissue dissection and an access length of $5-10 \mathrm{~cm}$ (19). The plate osteosynthesis can then be performed in MIPO technique (20). For example, from far lateral to far anterior by submuscular insertion of the plate, the lateral holes are managed through the axillary 

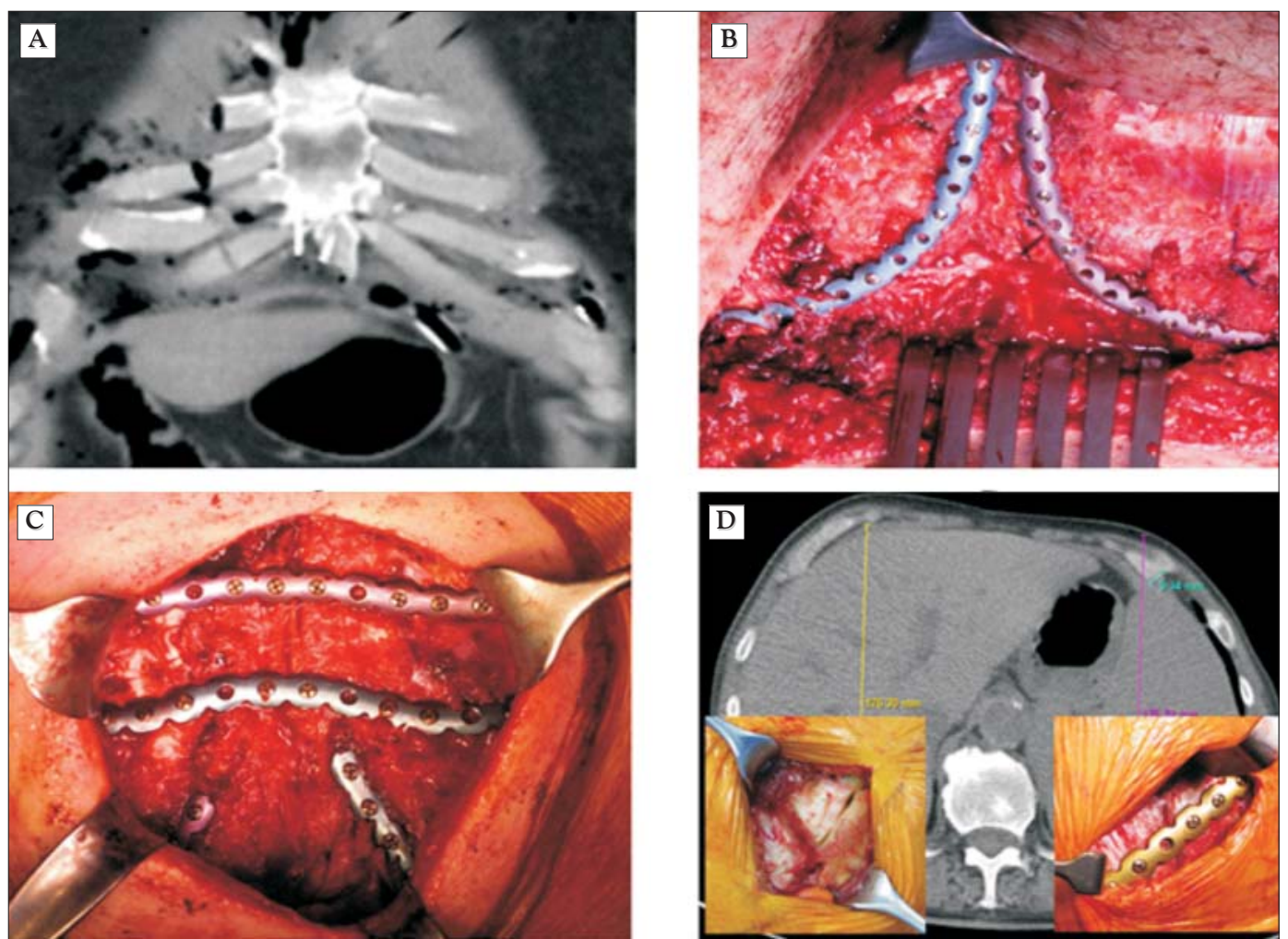

Figure 7. Possible options in the treatment of lower sternal fractures and those at the cartilage. (A) Multiple cartilage fractures and a transverse fracture of the sternum in the 4th intercostal space (case 14). (B) The operative fixation with a bilateral costo-sternal plate on the 7th rib provides reliable stability at the sternum as well as at the cartilage (case 14). (C) An oblique sternal fracture and concomitant fractures of the adjacent ribs had been fixed by ESCR on two levels. The cartilage of the 7th rib had been fixed with a costo-sternal plate on the 7th rib bilaterally (lower plates visible; case 7). (D) A dislocated fracture of the left lower rib arch (CT Scan, photograph on the left bottom) had been properly fixed by a locked plate (photograph on the right bottom)

access, the anterior one through the median sternal access (Fig. 3, 4).

Additional posterolateral and posterior fractures require a further approach to interspinoscapular, i.e. posterior, which needs to be performed in a lateral decubitus position what means to turn the patient out of the initial supine position.

Fractures of the lower rib arch can be addressed very well by a limited access path in fractures close to the sternum, eg the plate from the rib arch to the sternum (Fig. 7C). In the case of laterally situated fractures, the sole supply of this fracture is usually achieved by plate osteosynthesis (Fig. 7D). It is noteworthy that the screws of the plate system also ensure a sufficient hold in the ribs cartilage.

\section{Discussion}

The methodology presented gives an overview of the knowledge gained at our centers regarding the stabilization of complex FCI scenarios. Meanwhile, the locked plate osteosynthesis has developed into the most widespread and safest method for the operative therapy of sternum and rib fractures (21). Previously described dislocations of wires with sometimes severe intrathoracic injuries are thus excluded, a material failure and a secondary dislocation are minimized. A further safety aspect, also particularly for the inexperienced surgeon, is the depth limited drilling of the system (22). Thus, the thickness of the sternum or rib is determined at each region to be treated and a corresponding 
drill length is chosen that does not exceed the posterior cortex, thus excluding intrathoracic injuries.

In the treatment of chest wall fractures, accompanying intrathoracic injuries must, of course, also be included. Thus, the median anterior approach provides excellent accessibility to a possibly accompanying injury to the mammary arteries as well as, in worst case, to mediastinal injuries such as those of the heart. In this case an additional sternotomy would have to be carried out in order to reach the organs regularly. On the retreat of the operation, the sternotomy can be correspondingly stabilized with the additional fractures of the anterior chest wall. For example, a plate osteosynthesis over the sternotomy represent a sufficient method to address the rotatory instability analogous to the above-described manubrium fractures (23).

While submammary limited incisions are only suitable for the fixation of plates on the ribs accessible there above, an underlying thoracic pathology can, of course, be addressed via the axillary access routes. As a rule, lung lacerations lie in spatial relation to the dislocated ribs by injecting them into the parenchyma of the lung. A limited thoracotomy allows adequate access to these injuries and their care. At the same time, a pleural hematoma can be rinsed out and adequately drained. Of course, combination with video-assisted thoracoscopy (VATS) is also a good option at any time.

The follow-up examinations of the patients showed in all cases a normal wound healing. Special attention was paid to the functionality of the shoulder and the thoracic wall mobility, in particular, with the question whether the muscular system could recover properly. 4 patients showed moderate pulling pain after care for a period of 6 weeks to 6 months. 11 patients were nearly complaint-free after the 6 th week. As a postoperative regimen, we did not recommend a shoulder mobilization beyond the $90^{\circ}$ plane as a postoperative regimen with axial access and also posterior access and under strict relief of the shoulder to ensure healing of the detached shoulder- bearing muscles such as Latissimus dorsi, trapezius, rhomboideus and serratus anterior. The same applies to the anterior approach and the dissociated major pectoral muscles. In this respect, all patients showed an excellent outcome. There was no pectoral insufficiency, asymmetry, or other symptoms.

The Follow-up examinations showed a consistent consolidation during the X-ray controls of sternum and ribs in all cases without secondary dislocation of material or their implant failure. Nonunions were not observed as well as inflammatory reactions or pleural sequelae.

The use of other osteosynthesis materials may be discussed, in addition to locked plates, rib-clamp systems or an internal bracing of the chest wall could also be performed by means of bars. The clamp systems are managed through similar approaches as the rib plates. They encompass the rib and generally require slightly extended intercostal dissection, which is not generally associated with a higher risk of a lesion of intercostal vessels or nerves, but the biomechanical properties are based on a different principle from that of the locked plate osteosynthesis with a considerable risc of implant failure $(24,25)$. A retrosternal metal bar, as is very well known from the minimized pectus excavatum reconstructions according to Nuss, can also effect stabilization of the chest wall in certain cases. However, as a contraindication to this system, the sternum fracture is considered, although individual case reports also report successful stabilization of sternal fractures in the meantime $(26,27)$. However, some of these cases use plate osteosynthesis on the sternum as an additional protection similar to the one shown here. The condition for this procedure should be that the entire chest wall still remains soft in the composite, since the brace can, of course, not adequately reposition and retract multiple dislocated fractures. This is reserved for open reduction and surgical stabilization.

In summary, in the case of unstable chest wall injury, all regions of the bony chest wall must be examined and included in the stabilization options. If the indication for 
operative stabilization is established, a precise preoperative planning is usually required and recommended by a 3-dimensional reconstructed CT of the thorax, followed by a precise planning of the surgical access routes. The access routes shown in this manuscript allow the supply of almost the entire thoracic wall in combination of several minimized access routes. The incision can also be performed on the sternum in a limited way if the underlying fracture can be adequately addressed. On the one hand, the localization of the SF as well as its fracture course and direction of dislocation must be considered. Combinations of plate osteosynthesis in different directions can also lead to adequate stabilization, as can the use of special implants in T or I form. A long straight locked plate can be adapted to the rib shape and can fix the entire anterior chest wall from anterior right over sternum to anterior left in the sense of an elastic stable chest repair (28). This, too, can ideally be entered via several minimalized access routes (Fig. 3, 7C).

\section{Conclusions}

Combinations of SF and FCI are high risc injuries with a high demand on surgical skills. They can be properly fixed with a locked plate osteosynthesis through a combination of limited incisions employing different types of plates depending on the type and the location of the SF, such as the upper manubrium, the central sternum and the lower sternum.

\section{Acknowledgements}

Contents of this manuscript had been presented by the first author during the $18^{\text {th }}$ European Congress of Trauma and Emergency Surgery, 7.-9. May 2017 in Bucharest, Romania.

\section{Conflicts of Interest}

The first author has a consultant agreement with DePuySynthes and he is an advisory member of the AO TK Thoracic Surgery Expert Group (THEG).

\section{Ethical Policies}

This is a retrospective cohort study. No experiments on humans or animals had been done.

\section{Financial Support}

No funds had been received in connection to this study.

\section{References}

1. Schulz-Drost S, Oppel P, Grupp S, Krinner S, Langenbach A, Lefering $\mathrm{R}$, et al. Bony injuries of the thoracic cage in multiple trauma :Incidence, concomitant injuries, course and outcome. Unfallchirurg 2016;119(12):1023-1030. German

2. Schuurmans J, Goslings JC, Schepers T. Operative management versus non-operative management of rib fractures in flail chest injuries: a systematic review. Eur J Trauma Emerg Surg. 2017; 43(2):163-168. doi: 10.1007/s00068-016-0721-2.

3. Huber S, Biberthaler $P$, Delhey $P$, Trentzsch $H$, Winter $H$, van Griensven $\mathrm{M}$, et al. Predictors of poor outcomes after significant chest trauma in multiply injured patients: a retrospective analysis from the German Trauma Registry (Trauma Register DGU®). Scand J Trauma Resusc Emerg Med. 2014;22:52. doi: 10.1186/ s13049-014-0052-4.

4. Schulz-Drost S, Krinner S, Langenbach A, Oppel P, Lefering R, Taylor D, et al. Concomitant Sternal Fracture in Flail Chest: An Analysis of 21,741 Polytrauma Patients from the TraumaRegister DGU®. Thorac Cardiovasc Surg. 2017;65(7):551-559. doi: 10.1055/s-0037-1598194. Epub 2017 Feb 10.

5. Harston A, Roberts C. Fixation of sternal fractures: a systematic review. J Trauma. 2011;71(6):1875-9. doi: 10.1097/TA.0b013e31823c46e8.

6. Marasco S, Saxena P. Surgical rib fixation - technical aspects. Injury. 2015;46(5):929-32. doi: 10.1016/ j.injury.2014.12.021

7. Schulz-Drost S, Grupp S, Pachowsky M, Oppel P, Krinner S, Mauerer A, et al. Stabilization of flail chest injuries: minimized approach techniques to treat the core of instability. Eur J Trauma Emerg Surg. 2017;43(2):169-178. doi: 10.1007/s00068-016-0664-7

8. Bemelman M, van Baal M, Yuan JZ, Leenen L. The Role of Minimally Invasive Plate Osteosynthesis in Rib Fixation: A Review. Korean J ThoracCardiovasc Surg. 2016;49(1):1-8. doi: 10.5090/ kjtcs.2016.49.1.1.

9. Schulz-Drost S, Oppel P, Grupp S, Taylor D, Krinner S, Langenbach A, et al. The oblique fracture of the manubrium sterni caused by a seatbelt - a rare injury? Treatment options based on the experiences gained in a level I trauma centre. Int Orthop. 2016;40(4): 791-8. doi: 10.1007/s00264-015-2801-z. Epub 2015 May 10.

10. Schulz-Drost S, Oppel P, Grupp S, Schmitt S, Carbon RT, Mauerer A, et al. Surgical fixation of sternal fractures: preoperative planning and a safe surgical technique using locked titanium plates and depth limited drilling. J Vis Exp. 2015;(95):e52124. doi: 10.3791/ 52124.

11. Fowler AW. Flexion-compression injury of the sternum. J Bone Joint Surg Br 1957;39-B(3):487-97.

12. Alexander J. Traumatic pectusexcavatum. Ann Surg 1931;93(2): 489-500.

13. Kilic D, Findikcioglu A, Akin S, Akay TH, Kupeli E, Aribogan A, et al. Factors affecting morbidity and mortality in flail chest: comparison of anterior and lateral location. ThoracCardiovasc Surg. 2011;59(1): 45-8. doi: 10.1055/s-0030-1250597.

14. Scheyerer MJ, Zimmermann SM, Bouaicha S, Simmen HP, Wanner 
GA, Werner CM. Location of sternal fractures as a possible marker for associated injuries. Emerg Med Int. 2013;2013:407589. doi: 10.1155/2013/407589. Epub 2013 Nov 13.

15. Nirula R, Diaz JJ Jr, Trunkey DD, Mayberry JC. Rib fracture repair: indications, technical issues, and future directions. World J Surg 2009;33(1):14-22.

16. Leinicke JA, Elmore L, Freeman BD, Colditz GA. Operative management of rib fractures in the setting of flail chest: a systematic review and meta-analysis. Ann Surg. 2013;258(6):914-21 .

17. Harston A, Roberts $\mathrm{C}$. Fixation of sternal fractures: a systematic review. J Trauma. 2011;71(6):1875-9.

18. Schulz-Drost S, Syed J, Besendoerfer M, Carbon RT. Sternocostal dislocation following open correction of pectus excavatum"stairway phenomenon": complication management by means of sternocostal locking titanium plate osteosynthesis. Thorac Cardiovasc Surg. 2014;62(3):245-52. doi: 10.1055/s-0033-1356864. Epub 2013 Oct 14.

19. Schulz-Drost S, Grupp S, Pachowsky M, Oppel P, Krinner S, Mauerer A, et al. Stabilization of flail chest injuries: minimized approach techniques to treat the core of instability. Eur J Trauma Emerg Surg. 2017:43(2):169-178. doi: 10.1007/s00068-016-0664-7

20. Bemelman M, van Baal M, Yuan JZ, Leenen L. The role of minimally invasive plate osteosynthesis in Rib fixation: a review. Korean $\mathrm{J}$ Thorac Cardiovasc Surg. 2016;49(1):1-8. doi: 10.5090/ kjtcs.2016. 49.1.1.

21. Pieracci FM, Majercik S, Ali-Osman F, Ang D, Doben A, Edwards JG, et al. Consensus statement: Surgical stabilization of rib fractures rib fracture colloquium clinical practice guidelines. Injury. 2017; 48(2):307-321. doi: 10.1016/j.injury. 2016.11.026
22. Schulz-Drost S, Mauerer A, Grupp S, Hennig FF, Blanke M. Surgical fixation of sternal fractures: locked plate fixation by low-profile titanium plates - surgical safety through depth limited drilling. Int Orthop. 2014;38(1):133-9.

23. Fawzy H, Alhodaib N, Mazer CD, Harrington A, Latter D, Bonneau $D$, et al. Sternal plating for primary and secondary sternal closure; can it improve sternal stability? J Cardiothorac Surg. 2009;4:19. doi: 10.1186/1749-8090-4-19.

24. Wiese MN, Kawel-Boehm N, Moreno de la Santa P, Al-Shahrabani F, Toffel M, Rosenthal R, et al. Functional results after chest wall stabilization with a new screwless fixation device. Eur $\mathrm{J}$ Cardiothorac Surg. 2015;47(5):868-75. doi: 10.1093/ejcts/ezu318.

25. Sharma PK, Willems TP, Touw DJ, Woudstra W, Erasmus ME, Ebels T. Implant Failure: STRATOS System for Pectus Repair. Ann Thorac Surg. 2017;103(5):1536-1543.

26. Ke S, Duan H, Cai Y, Kang J, Feng Z. Thoracoscopy-assisted minimally invasive surgical stabilization of the anterolateral flail chest using Nuss bars. Ann Thorac Surg. 2014;97(6):2179-82. doi: 10.1016/i.athoracsur.2013.08.066

27. Akkus M, Utkusavaș A, Hanözü M, Kaya M, Bakir I. Stabilization of Flail Chest and Fractured Sternum by Minimally Invasive Repair of Pectus Excavatum. Thorac Cardiovasc Surg Rep. 2015;4(1):11-3. doi: 10.1055/s-0035-1563399.

28. Schulz-Drost S, Syed J, Besendoerfer M, Mauerer A, Blanke M, Schulz-Drost M, et al. Elastic stable chest repair as a means of stabilizing the anterior chest wall in recurrent pectus excavatum with sternocostal pseudarthrosis: an innovative fixation Device. Thorac Cardiovasc Surg. 2015;63(5):419-26. doi: 10.1055/s-00341372333. 